\title{
Assessment of the floristic composition of sward grazed by various animal species
}

\author{
Zbigniew Czarnecki ${ }^{1 *}$, Teresa Wyłupek², Wanda Harkot ${ }^{1}$ \\ 'Department of Grassland and Landscape Forming, University of Life Sciences in Lublin, Akademicka 15, 20-950 Lublin, Poland \\ ${ }^{2}$ Department of Plant Biology, Faculty of Agricultural Sciences in Zamość, University of Life Sciences in Lublin, Szczebrzeska 102, 22-400 Zamość, Poland
}

\begin{abstract}
The study objective was to assess the floristic composition of pastures for wild animals (fallow deer, Manchurian deer and mouflons) at Przytoczno, pastures for horses at Białka, and cow pastures belonging to the Land Community in Tarnogóra. We analyzed the floristic composition of the pastures under study in the growing seasons of 2011 and 2012, carried out 32 phytosociological relevés in the wild animal pastures, 32 in the horse pastures, and 38 in the cow pastures, using the BraunBlanquet method. We determined the species diversity of the pastures based on the percentage share of species from the botanical families distinguished, the total number of species, and the Shannon-Wiener and Simpson diversity index. Our floristic surveys indicated that the greatest species diversity occurred in the horse pastures, while it was lower in the wild animal and cow pastures. The Shannon-Wiener diversity index for the sward of the pastures grazed by horses was higher $\left(H^{\prime}=5.04\right)$ than for those grazed by wild animals $\left(H^{\prime}=4.32\right)$ and cows $\left(H^{\prime}=3.53\right)$. The Simpson index of species diversity in a community was higher for the pastures grazed by horses $(S=0.96)$ than for those grazed by wild animals $(S=0.95)$ and cows $(S=0.90)$.
\end{abstract}

Keywords: pastures; biodiversity; wild animals; horses; cows; extensive grazing

\section{Introduction}

The area of unused meadow and pasture land in Poland has been increasing in recent years. The main reason for that is the lower profitability of animal production, which has contributed to numerous irregularities in the maintenance of permanent grasslands [1]. Due to the lack of spending on land drainage management and due to the abandonment of fertilization and, in some cases, utilization, meadows often become marshy again, which results in economic and environmental losses. Such processes lead to a poorer floristic composition, deterioration of the turf cover and a decline in the quantity and quality of fodder obtained $[2,3]$.

Extensive grazing of animals is a significant factor determining the floristic richness of permanent grasslands. Changes in the botanical composition of the sward can follow different courses depending on the habitat conditions, the level and manner of pasture management as well as the species, age and breed of animals [4-8].

The objective of the present study was to assess the floristic composition of the sward grazed by different kinds of

*Corresponding author. Email: zbigniew.czarnecki@up.lublin.pl

Handling Elżbieta Weryszko-Chmielewska animals: wild animals (fallow deer, Manchurian deer, and mouflons), horses, and cows.

\section{Material and methods}

We assessed the floristic composition of pastures for wild animals (fallow deer, Manchurian deer, and mouflons) at Przytoczno (15 ha), pastures for horses at Białka (14.5 ha), and cow pastures belonging to the Land Community in Tarnogóra (132 ha). The area grazed by wild animals at Przytoczno was divided into six feedlots. Feedlot No. 1, 2 and 6 and about $30 \%$ of the area of feedlot No. 3 are located in a depression (the feedlots are dissected by a drainage ditch). Therefore, these feedlots are characterized by considerably greater humidity in comparison with the other ones. Wild animals stay on the feedlots all year round. In the winter, the animals are fed with hay silage, hay and cereal grain (mainly oats, maize, triticale and barley). The horse pastures at the Stalion Depot at Białka were established in the 1970s, and in the 1990s some of the pastures were additionally seeded with grass mixes in order to improve their usefulness (there is no source data concerning the species composition of the mixes). Currently, the pastures cover 14.41 ha ( 8 feedlots) and are grazed by a herd of 241 horses. 
The pastures supplement the basic diet, i.e. nutritive fodder, and allow the horses space for movement and exercise. Horses stay on the pastures from 15 May to 15 October, for several hours a day (except Saturdays and Sundays). In the remaining months, in favorable atmospheric conditions, the pasture is used as a paddock in order to keep the animals fit. Maintenance measures such as mineral fertilization and irrigation are not used, and maintenance cutting is carried out only sporadically. The floristic composition of the cow pastures was investigated on extensive pastures located in the valley of the Wieprz river in Tarnogóra (Izbica municipality, Lubelskie Province). This part of the Wieprz valley belongs to a large Natura 2000 habitat area PLH060030 - the Izbica Wieprz Gap. The pastures are located on muck and bog soils originating from mineral alluvial and deluvial sediments, rich in organic matter, and are characterized by varying water content (from the optimum to boggy to periodically waterlogged and flooded). The pastures belong to the socalled Land Community established more than 100 years ago. Currently. the Land Community manages about 200 ha of land, including 132 ha of pastures, 55 ha of forests and 13 ha of arable land. Cow grazing begins around 1 May and lasts approximately until 1 November.

We analyzed the floristic composition of the pastures under study in the growing seasons of 2011 and 2012, using the Braun-Blanquet method. We carried out 32 phytosociological relevés in the Przytyczno wild animal pastures, 32 in the Białka horse pastures and 38 in the Tarnogóra cow pastures. We determined the species diversity of the pastures based on the percentage share of species from the botanical families distinguished, the total number of species and the Shannon-Wiener diversity index. The Shannon-Wiener diversity index is defined as a negative sum of the product of the probable significance of the subsequent species in the dataset and the logarithm of the probability:

$$
H^{\prime}=-\sum p_{i} \log p_{i}
$$

where $p_{i}$ is the probable significance of the $i$ th species in the dataset: $p_{i}=n_{i} / N, n_{i}$ is the significance coefficient of a given species, and $N$ denotes the sum of significance coefficients of all species. The value of this index is relatively permanent for samples of varying size and is determined mainly by the value of the share of the species. The Simpson index of species diversity in a community is based on the coefficient of predominance or concentration of a multispecies community [9]:

$$
\lambda=\sum p_{i}^{2}
$$

where $p_{i}$ denotes the probable significance of the $i$ th species in the dataset. The index was proposed by Simpson [10] as a measure of concentration. It represents the degree of probability of every two randomly selected specimens in a given community belonging to the same species. Thus, the Simpson index is an inverse measure in relation to the Shannon-Wiener diversity index because the likelihood of two random specimens belonging to the same species is greater in communities with lower diversity.

We also determined the percentage share of life forms using the Raunkiær system, according to the study by
Zarzycki et al. [11]. We used the species nomenclature according to Mirek et al. [12].

\section{Results}

Our floristic surveys indicated that the greatest species diversity occurred in the Białka horse pastures, while it was lower in the Przytoczno wild animal pastures and the Tarnogóra cow pastures (Tab. 1 and Tab. 2).

A total of 69 plant species were distinguished in the sward of the horse pastures, namely 17 grass species, 9 legume species and 43 species of other botanical families. In the wild animal pastures, we distinguished a total of 50 species, i.e. 15 grass species, 4 legume species and 31 species of other botanical families. In the cow pastures belonging to the Land Community in Tarnogóra, a total of 37 plant species occurred, including 14 grass species, 3 legume species and 20 species of other botanical families. The following species had a considerable share in the pastures under study: Taraxacum officinale $( \pm 20.0 \%)$, Trifolium repens $( \pm 24.1 \%)$, Elymus repens $( \pm 10.1 \%)$, Agrostis capillaris $( \pm 20.4 \%)$, Dactylis glomerata (2.5-36.0\%), Festuca pratensis ( $\pm 12.9 \%)$, Festuca rubra ( $\pm 25.0 \%)$, Lolium perenne (1.0-32\%), Poa annua $( \pm 9.7 \%)$, Poa pratensis (1.0-10.7\%) and Ranunculus repens $( \pm 9.0 \%)$. The share of the other species in the sward of the pastures under study was considerably smaller and did not exceed $9 \%$ of the sward species composition. The Poaceae (25), Asteraceae (13) and Fabaceae (10) families had the greatest number of species. The other botanical families were represented by a considerably lower number of taxa, namely Caryophyllaceae, Cyperaceae, Lamiaceae, Plantaginaceae, Polygonaceae, Ranunculaceae and Rosaceae were represented by four taxa each; Rubiaceae and Scrophulariaceae by three taxa each; Brassicaceae and Juncaceae by two taxa each; Aliaceae, Boraginaceae, Chenopodiaceae, Convolvulaceae, Dipsaceae, Geraniaceae, Primulaceae, Urticaeae and Violaceae by one taxon each (Tab. 2).

The Shannon-Wiener diversity index for the sward of the pastures grazed by horses was higher $\left(H^{\prime}=5.04\right)$ than for those grazed by wild animals $\left(H^{\prime}=4.32\right)$ and cows $\left(H^{\prime}=3.53\right)$; see Tab. 3. The Simpson index of species diversity in a community was also higher for the pastures grazed by horses $(S=0.96)$ than for those grazed by wild animals $(S=0.95)$ and cows $(S=0.90)$.

The pastures grazed by cows (Fig. 1) had a higher share of hydrophytes and helophytes (15.0\%) than the pastures grazed by wild animals $(1.6 \%)$ and horses (1.3\%). The reason for the considerable share of hydrophytes in the cow pastures is that they are located in the valley of the Wieprz river, in humid habitats, among natural ditches, still water pools and small ponds. This group of plants was represented by Carex acutiformis, Rorippa amphibia, Eleocharis palustris, Mentha arvensis, Hippuris vulgaris, Glyceria fluitans, Glyceria maxima and Veronica beccabunga. Therophyte species occurred only on pastures grazed by horses (10.5\%) and wild animals (19.7\%).

They were represented by Conyza canadensis, Matricaria inodora, Senecio vernalis, Capsella bursa-pastoris, Melandrium album, Chenopodium album, Medicago lupulina, 
Tab. 1 The share of species in the sward of the pastures under study, their life-forms according to Raunkiær and the botanical families.

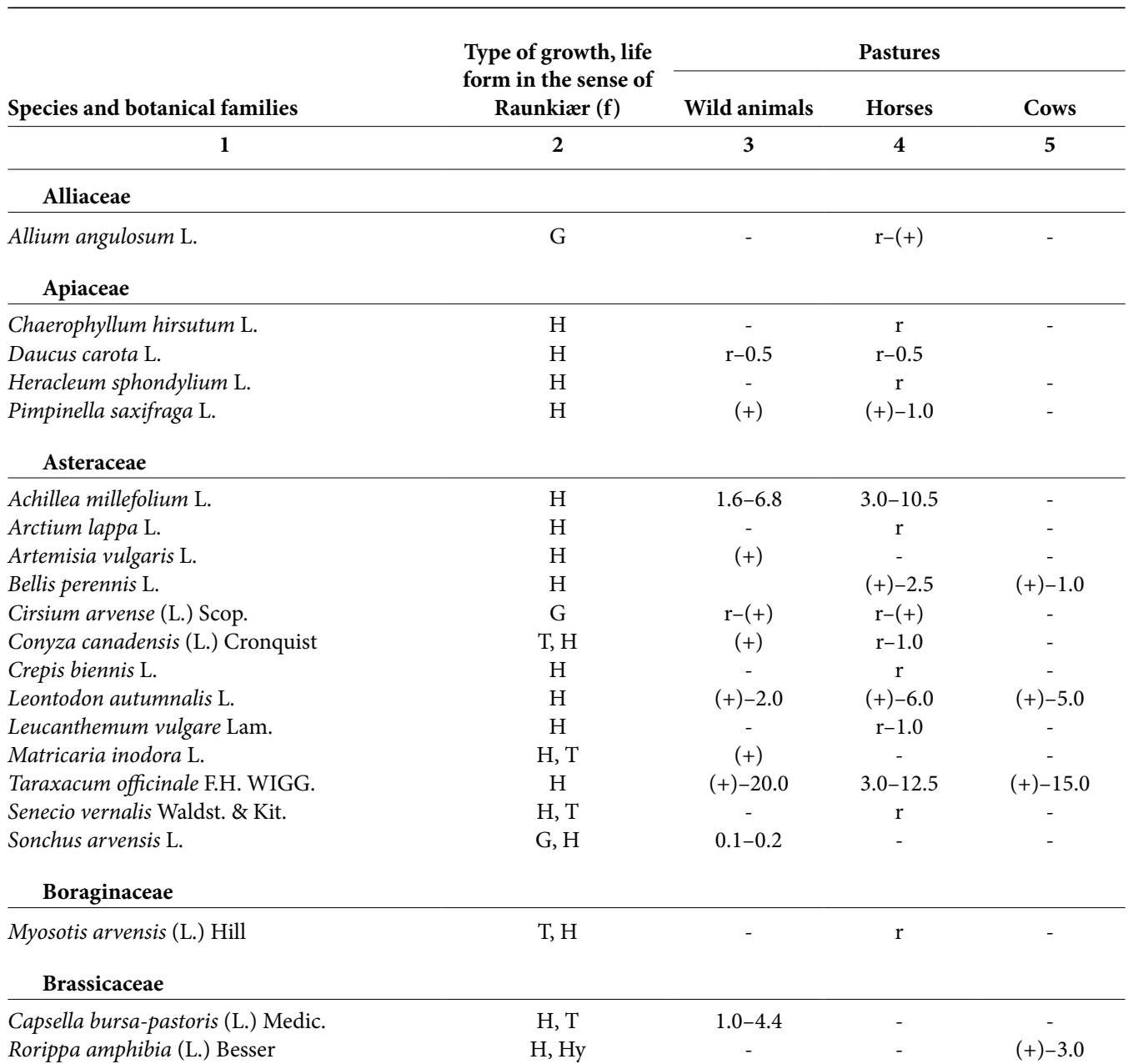

\section{Caryophyllaceae}

Cerastium holosteoides Fr. em. Hyl. Melandrium album (MILL.) GARCKE

Stellaria graminea $\mathrm{L}$.

Stellaria media (L.) VILL.

$\begin{array}{ccc}\mathrm{C}, \mathrm{H} & 6.8 & (+) \\ \mathrm{T}, \mathrm{H} & (+) & \mathrm{r}-(+) \\ \mathrm{H} & (+)-2.1 & \mathrm{r}-(+) \\ \mathrm{T}, \mathrm{H} & (+)-4.4 & -\end{array}$

Chenopodiaceae

Chenopodium album L.

$\mathrm{T}$

$(+)$

Convolvulaceae

Convolvulus arvensis $\mathrm{L}$.

G, H, li

r

\section{Cyperaceae}

Carex acutiformis Ehrh.

Carex hirta L.

Eleocharis palustris (L.) Roem. \& Schult.

Scirpus sylvaticus $\mathrm{L}$.

$\begin{array}{cccc}\text { G, Hy } & - & - & 5.0-62.5 \\ \text { G } & - & - & (+)-5.0 \\ \text { Hy, G } & - & - & 5.0 \\ \text { G } & - & - & 4.0\end{array}$

Dipsacaceae

Knautia arvensis (L.) J.M. Coult.

$\mathrm{H} \quad-\quad r-(+)$

Fabaceae

Lathyrus pratensis L.

Lotus corniculatus L.

Lupinus angustifolius $\mathrm{L}$.

Medicago lupulina $\mathrm{L}$.

Trifolium aureum Pollich

$\mathrm{r}-(+)$

Trifolium hybridum L.

Trifolium pratense L.

Trifolium repens $\mathrm{L}$.

$\begin{array}{cccc}\mathrm{H} & - & \mathrm{r}-1.0 & - \\ \mathrm{H} & - & (+)-5.0 & - \\ \mathrm{H} & - & \mathrm{r} & - \\ \mathrm{H}, \mathrm{T} & (+)-1.0 & (+)-8.0 & - \\ \mathrm{H}, \mathrm{T} & - & (+)-1.0 & - \\ \mathrm{H} & - & - & (+)-5.0 \\ \mathrm{H} & (+)-0.5 & (+)-4.0 & (+)-15.0 \\ \mathrm{C}, \mathrm{H} & 1.5-24.1 & (+)-11.0 & 15.0-62.5 \\ \mathrm{H} & \mathrm{r}-(+) & \mathrm{r}-1.0 & -\end{array}$

Vicia cracca L. 
Tab. 1 (continued)

\begin{tabular}{cccc}
\hline $\mathbf{1}$ & $\mathbf{2}$ & $\mathbf{3}$ & $\mathbf{4}$ \\
\hline Vicia tetrasperma (L.) Schreb. & $\mathrm{T}$ & - & $\mathrm{r}$
\end{tabular}

Geraniaceae
$\begin{aligned} & \text { Geranium pratense L. } \\ & \text { Juncaceae }\end{aligned}$

\begin{tabular}{lllc}
\hline Juncus articulatus L. em. K. Richt. & $\mathrm{H}$ & - & - \\
Luzula campestris (L.) DC. & $\mathrm{H}$ & - & $\mathrm{r}-(+)-5.0$
\end{tabular}

\section{Lamiaceae}

Glechoma hederacea $\mathrm{L}$

Mentha arvensis L.

Prunella vulgaris $\mathrm{L}$.

Salvia pratensis $\mathrm{L}$.

$\begin{array}{cccc}\text { G, H } & (+)-3.0 & (+) & - \\ \text { G, Hy } & 0.5-4.2 & - & - \\ \text { H } & - & \mathrm{r}-(+) & 1.0 \\ \mathrm{H} & - & \mathrm{r} & -\end{array}$

\section{Plantaginaceae}

Hippuris vulgaris $\mathrm{L}$.

Plantago lanceolata L.

Plantago major L.

Plantago media L.

$\begin{array}{cccc}\text { Hy } & - & - & (+)-5.0 \\ \mathrm{H} & (+)-1.7 & \mathrm{r}-1.0 & (+)-5.0 \\ \mathrm{H} & (+)-7.5 & \mathrm{r}-4.5 & - \\ \mathrm{H} & (+) & \mathrm{r}-2.0 & (+)\end{array}$

\section{Poaceae}

\begin{tabular}{|c|c|c|c|c|}
\hline Elymus repens (L.) Gould & G & $(+)-10.1$ & $1.0-10.0$ & $1.0-15.0$ \\
\hline Agrostis capillaris L. & $\mathrm{H}$ & $4.2-20.4$ & $(+)-4.0$ & $1.0-15.0$ \\
\hline Agrostis stolonifera L. & $\mathrm{H}$ & - & - & $(+)-37.5$ \\
\hline Alopecurus pratensis L. & $\mathrm{H}$ & - & $\mathrm{r}-4.0$ & - \\
\hline Anthoxanthum odoratum L. & $\mathrm{H}$ & - & $(+)$ & - \\
\hline Apera spica-venti (L.) P. Beauv. & $\mathrm{T}, \mathrm{H}$ & 0.1 & - & - \\
\hline Avenula pubescens (Huds.) Dumort. & $\mathrm{H}$ & $(+)$ & $(+)$ & - \\
\hline Bromus inermis Leyss. & $\mathrm{H}$ & 4.0 & $\mathrm{r}-(+)$ & - \\
\hline Bromus hordeaceus L. & $\mathrm{T}$ & $0.1-7.5$ & $(+)-3.0$ & - \\
\hline Bromus unioloides L. & $\mathrm{T}$ & - & r & - \\
\hline Cynosurus cristatus L. & $\mathrm{H}$ & - & - & $1.0-62.0$ \\
\hline Dactylis glomerata L. & $\mathrm{H}$ & $2.5-20.5$ & $14.0-36.0$ & - \\
\hline Deschampsia caespitosa (L.) P. Beauv. & $\mathrm{H}$ & $(+)$ & - & $5.0-62.5$ \\
\hline Echinochloa crus-galli (L.) P.B. & $\mathrm{T}$ & $(+)-0.1$ & - & - \\
\hline Festuca arundinacea Schreb. & $\mathrm{H}$ & - & $\mathrm{r}-(+)$ & - \\
\hline Festuca pratensis HUDS & $\mathrm{H}$ & $0.8-12.9$ & $(+)-2.0$ & $1.0-37.5$ \\
\hline Festuca rubra L.S.S. & $\mathrm{H}$ & $4.5-24.0$ & $5.0-25.0$ & $(+)-15.0$ \\
\hline Glyceria fluitans (L.) R. Br. & Hy & - & - & $1.0-15.0$ \\
\hline Glyceria maxima (Hartm.) Holmb. & Hy & - & - & $1.0-32.5$ \\
\hline Lolium perenne L. & $\mathrm{H}$ & $14.4-31.0$ & $10.0-32.0$ & $1.0-32.0$ \\
\hline Phleum pratense L. & $\mathrm{H}$ & $0.5-9.0$ & $(+)-2.0$ & $1.0-15.0$ \\
\hline Poa annua L. & $\mathrm{H}, \mathrm{T}$ & $5.4-9.7$ & $(+)-5.0$ & - \\
\hline Poa palustris L. & $\mathrm{H}$ & - & - & 5.0 \\
\hline Poa pratensis L. & $\mathrm{H}$ & $0.5-10.7$ & $1.0-5.5$ & $1.0-37.5$ \\
\hline Poa trivialis $\mathrm{L}$. & $\mathrm{H}$ & - & $(+)-1.0$ & $1.0-37.6$ \\
\hline
\end{tabular}

\section{Polygonaceae}

Polygonum persicaria $\mathrm{L}$ Polygonum aviculare L.

Rumex acetosa $\mathrm{L}$.

Rumex crispus L.

$\begin{array}{cc}\mathrm{T} & 2.0 \\ \mathrm{~T} & (+)-7.5 \\ \mathrm{H} & -\end{array}$

2.0
$+)-7.5$

$\mathrm{r}-1.5$

$\mathrm{r}-(+)$

$\mathrm{H} \quad \mathrm{r}-1.5 \quad \mathrm{r} \quad(+)-5.0$

Primulaceae

\begin{tabular}{lllll}
\hline Lysimachia nummularia L. & C & 0.2 & $\mathrm{r}-(+)$ & $(+)-5.0$
\end{tabular}

Ranunculaceae

Caltha palustris L. subsp. palustris

$\begin{array}{cccc}\mathrm{H} & - & & (+)-5.0 \\ \mathrm{H} & - & \mathrm{r} & - \\ \mathrm{G}, \mathrm{H} & - & \mathrm{r} & - \\ \mathrm{H} & (+)-0.4 & (+)-9.0 & 1.0-37.0\end{array}$

Ranunculus acris L. s.s.

Ranunculus repens $\mathrm{L}$.

$(+)-0.4$

$(+)-9.0$

$.0-37.0$

\section{Rosaceae}

Alchemilla monticola Opiz

Geum rivale L.

Potentilla anserina $\mathrm{L}$.

Potentilla erecta (L.) Raeusch.

$\begin{array}{lccc}\mathrm{H} & - & \mathrm{r} & - \\ \mathrm{H} & - & \mathrm{r} & - \\ \mathrm{H} & \mathrm{r}-4.0 & - & (+)-15.0 \\ \mathrm{H} & - & \mathrm{r} & -\end{array}$


Tab. 1 (continued)

\begin{tabular}{lcccc}
\hline \multicolumn{1}{c}{$\mathbf{1}$} & $\mathbf{2}$ & $\mathbf{3}$ & $\mathbf{4}$ & $\mathbf{5}$ \\
\hline \multicolumn{1}{c}{ Rubiaceae } & & & & \\
\hline Galium mollugo L. & $\mathrm{H}$ & - & - & $(+)-15.0$ \\
Galium palustre L. & $\mathrm{H}$ & - & - & $1.0-15.5$ \\
Galium verum L. & $\mathrm{H}$ & - & $\mathrm{r}-1.0$ & - \\
$\quad$ Scrophulariaceae & & & & \\
\hline Veronica beccabunga L. & $\mathrm{Hy}, \mathrm{C}$ & - & $\mathrm{r}-1.0$ & - \\
Veronica chamaedrys L. & $\mathrm{C}$ & $0.1-2.6$ & $(+)-2.0$ & - \\
Veronica serpyllifolia L. & $\mathrm{H}$ & - & $\mathrm{r}-1.0$ & - \\
$\quad$ Urticaceae & & & & - \\
\hline Urtica dioica L. & $\mathrm{H}$ & $(+)$ & $\mathrm{r}-(+)$ & - \\
$\quad$ Violaceae & & & & 37 \\
\hline Viola arvensis MURRAY & $\mathrm{T}$ & $(+)$ & - & 69 \\
Number of species & & 50 & & \\
\hline
\end{tabular}

$\mathrm{f}$ - type of growth, life form in the sense of Raunkiær (according to position of buds during winter): $\mathrm{H}$ - hemikryptophyte, buds near the ground; Hy - hydrophyte and helophyte, aquatic plant with normally submerged buds; C - herbaceous chamaephyte, herb with buds $<25 \mathrm{~cm}$ above the ground; $\mathrm{G}$ - geophyte, buds within the soil, often with storage organs; $\mathrm{T}$ - therophyte, short-lived, annual; li - liana, rooting in the soil but leaning on other plants; "+" - rarely occurring species; $r$ - sporadically occurring species.

Tab. 2 Species richness and floristic diversity of the pastures under study depending on the species of the grazing animals.

\begin{tabular}{|c|c|c|c|c|c|c|c|c|}
\hline \multirow[b]{3}{*}{ Family } & \multicolumn{6}{|c|}{ Pastures } & & \\
\hline & \multicolumn{2}{|c|}{ Wild animals } & \multicolumn{2}{|c|}{ Horses } & \multicolumn{2}{|c|}{ Cows } & \multicolumn{2}{|c|}{ Total } \\
\hline & $\begin{array}{l}\text { Number } \\
\text { of species }\end{array}$ & $\begin{array}{c}\text { Share } \\
(\%)\end{array}$ & $\begin{array}{l}\text { Number } \\
\text { of species }\end{array}$ & $\begin{array}{c}\text { Share } \\
(\%)\end{array}$ & $\begin{array}{l}\text { Number } \\
\text { of species }\end{array}$ & $\begin{array}{c}\text { Share } \\
(\%)\end{array}$ & $\begin{array}{l}\text { Number } \\
\text { of species }\end{array}$ & $\begin{array}{c}\text { Share } \\
(\%)\end{array}$ \\
\hline Alliaceae & - & - & 1 & 1.4 & - & - & 1 & 1.0 \\
\hline Apiaceae & 2 & 4.0 & 4 & 5.8 & - & - & 4 & 4.0 \\
\hline Asteraceae & 8 & 16.0 & 10 & 14.6 & 3 & 8.1 & 13 & 13.2 \\
\hline Boraginaceae & - & - & 1 & 1.4 & - & - & 1 & 1.0 \\
\hline Brassicaceae & 1 & 2.0 & - & - & 1 & 2.7 & 2 & 2.1 \\
\hline Caryophyllaceae & 4 & 8.0 & 3 & 4.4 & - & - & 4 & 4.0 \\
\hline Chenopodiaceae & 1 & 2.0 & - & - & - & - & 1 & 1.0 \\
\hline Convolvulaceae & - & - & 1 & 1.4 & - & - & 1 & 1.0 \\
\hline Cyperaceae & - & - & - & - & 4 & 10.8 & 4 & 4.0 \\
\hline Dipsacaceae & - & - & 1 & 1.4 & - & - & 1 & 1.0 \\
\hline Fabaceae & 4 & 8.0 & 9 & 13.1 & 3 & 8.1 & 10 & 10.1 \\
\hline Geraniaceae & 1 & 2.0 & 1 & 1.4 & - & - & 1 & 1.0 \\
\hline Juncaceae & - & - & 1 & 1.4 & 1 & 2.7 & 2 & 2.1 \\
\hline Lamiaceae & 2 & 4.0 & 3 & 4.4 & 1 & 2.7 & 4 & 4.0 \\
\hline Plantaginaceae & 3 & 6.0 & 3 & 4.4 & 3 & 8.1 & 4 & 4.0 \\
\hline Poaceae & 15 & 30.0 & 17 & 24.6 & 14 & 37.9 & 25 & 25.3 \\
\hline Polygonaceae & 3 & 6.0 & 2 & 2.9 & 1 & 2.7 & 4 & 4.0 \\
\hline Primulaceae & 1 & 2.0 & 1 & 1.4 & 1 & 2.7 & 1 & 1.0 \\
\hline Ranunculaceae & 1 & 2.0 & 3 & 4.4 & 2 & 5.4 & 4 & 4.0 \\
\hline Rosaceae & 1 & 2.0 & 3 & 4.4 & 1 & 2.7 & 4 & 4.0 \\
\hline Rubiaceae & - & - & 1 & 1.4 & 2 & 5.4 & 3 & 3.1 \\
\hline Scrophulariaceae & 1 & 2.0 & 3 & 4.4 & - & - & 3 & 3.1 \\
\hline Urticaceae & 1 & 2.0 & 1 & 1.4 & - & - & 1 & 1.0 \\
\hline Violaceae & 1 & 2.0 & - & - & - & - & 1 & 1.0 \\
\hline
\end{tabular}


Tab. 3 The Shanonn-Wiener diversity index and the Simpson index of species diversity in a community for the pastures under study.

\begin{tabular}{|c|c|c|c|c|c|c|}
\hline \multirow[b]{3}{*}{ Diversity index } & \multicolumn{6}{|c|}{ Pastures } \\
\hline & \multicolumn{2}{|c|}{ Wild animals } & \multicolumn{2}{|c|}{ Horses } & \multicolumn{2}{|c|}{ Cows } \\
\hline & Mean & Range & Mean & Range & Mean & Range \\
\hline Shannon-Wiener & 4.32 & $3.91-4.63$ & 5.04 & $4.60-5.62$ & 3.53 & $3.02-3.77$ \\
\hline Simpson & 0.95 & $0.93-0.96$ & 0.96 & $0.95-0.98$ & 0.90 & $0.86-0.94$ \\
\hline
\end{tabular}
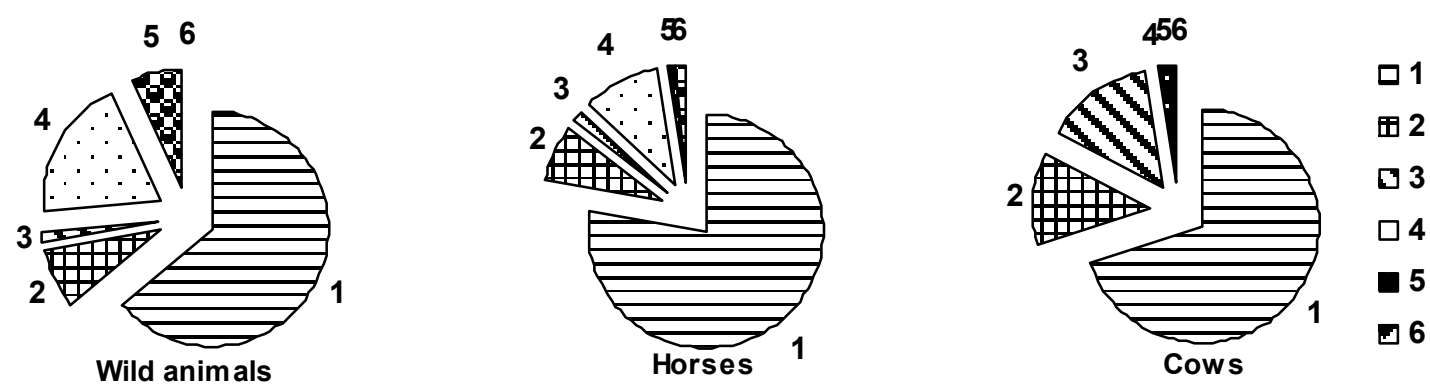

Fig. 1 Percentage share of life-forms according to the Raunkiær classification (1 - hemicryptophyte; 2 - geophyte; 3 - hydrophyte and helophyte; 4 - therophyte; 5 - herbaceous chamaephyte; 6 - liana).

Trifolium aureum, Vicia tetrasperma, Apera spica-venti, Bromus hordeaceus, Echinochloa crus-galli, Poa annua, Polygonum persicaria, Polygonum aviculare and Viola arvensis. Hemicryptophytes were represented by 77 taxa and they had a greater share in the sward of the pastures for horses (77\%) than those for cows (70.0\%) and wild animals (63.9\%). Geophytes were represented by Allium angulosum, Cirsium arvense, Sonchus arvensis, Convolvulus arvensis, Carex acutiformis, Carex hirta, Eleocharis palustris, Scirpus sylvaticus, Glechoma hederacea, Mentha arvensis, Elymus repens and Ranunculus bulbosus. Geophytes had a greater share in the pastures for cows (12.5\%) than those for wild animals (8.2\%) and horses (7.9\%).

\section{Discussion}

The pastures for wild animals, horses and cows were characterized by varied floristic composition. A total of 50 plant species occurred in the sward of the pastures for wild animals, 69 species in those for horses and 37 in those for cows. The number of taxa forming the plant communities of grasslands is influenced by various factors, among which the most important are: type of sward use, fertilization [13-15], elevation of the area above sea level, water content in the habitats, soil $\mathrm{pH}$, land slope and exposure, and granulometric composition of the soil [16-19]. Greater floristic richness usually occurs in the sward of cut meadows rather than grazed pastures, mainly because animals use the sward selectively. The Shannon-Wiener diversity index for the sward of the pastures grazed by horses at Białka was higher $\left(H^{\prime}=5.04\right)$ than for those grazed by wild animals at
Przytoczno $\left(H^{\prime}=4.32\right)$ and cows at Tarnogóra $\left(H^{\prime}=3.53\right)$. The studies by Rogalski et al. [19] also show that the Shannon-Wiener diversity index for the sward of pastures grazed by cattle is lower $\left(H^{\prime}=0.84\right)$ than for those grazed by horses $\left(H^{\prime}=1.38\right)$. Rogalski et al. [19] suggests that the floristic diversity in pastures for cattle is the lowest, while it is higher in pastures for horses. Joint grazing by various animal species also reduces biodiversity.

A total of 99 plant species from 24 botanical families were identified in the pastures under study (Przytoczno, Białka and Tarnogóra). The study by Mosek [6] reveal the occurrence of 124 plant species in pasture communities in the river valleys of the Lublin Region. According to Grodzińska and Zarzycki [20], 108 plant species occur in lowland pastures and 121 plant species occur in mountain pastures. In the meadows and pastures of the Dynów Foothills, 363 vascular plant species belonging to 54 families were found, including 42 grass species, 29 legume species, 41 bulrush species and 28 sedge species [21].

The large species diversity of the pastures for horses (69 species) results from their extensive, long-standing utilization. The literature indicates that extensive utilization of pastures for horses is highly conducive to their floristic richness $[8,19,22]$. Other studies showed that intensive and long-standing grazing of the sward by horses reduces the species composition more than intensive grazing by cattle [17].

The prevalence of hydrophytes and helophytes (Hy) in the pastures under study is an indicator of the natural abundance of surface waters and various kinds of humid habitats in these areas. A considerably greater share of hydrophytes and helophytes occurred in the pastures grazed by cows at Tarnogóra $(15.0 \%)$ than in the pastures grazed by wild 
animals at Przytoczno (1.6\%) and by horses at Białka (1.3\%). This group of plants was represented by Carex acutiformis, Rorippa amphibia, Eleocharis palustris, Mentha arvensis, Hippuris vulgaris, Glyceria fluitans, Glyceria maxima and Veronica beccabunga. Thus, species characteristic of humid, even periodically flooded, habitats were numerous in the pastures grazed by cattle. The reason for periodic flooding of the cow pastures at Tarnogóra is the unregulated stretch of the Wieprz river. The pastures are situated among natural ditches, still water pools and small ponds. The surrounding vegetation consists of water and marsh rushes from the Phragmitetea class. The pastures are located on muck and bog soils originating from mineral alluvial and diluvial sediments, rich in organic matter, and are characterized by varying water content (from the optimum to boggy to periodically waterlogged and flooded).

\section{Conclusions}

The pastures were characterized by a rich floristic composition. A total of 99 plant species belonging to 24 botanical families occurred in the sward of all the pastures. 50 species occurred in the pastures extensively grazed by wild animals

\section{Acknowledgments}

The research was supported by the Ministry of Science and Higher Education of Poland as a part of the activities of the Department of Grassland and Landscape Forming, University of Life Sciences in Lublin.

\section{Authors' contributions}

The following declarations about authors' contributions to the research have been made: study conception and design: $\mathrm{CZ}, \mathrm{WT}, \mathrm{WH}$; acquisition of data: CZ, WT; analysis and interpretation of data: CZ, WT; drafting of manuscript: CZ, WT.

\section{Competing interests}

No competing interests have been declared.

\section{References}

1. Jankowska-Huflejt H, Domański PJ. Present and possible directions of utilising permanent grasslands in Poland. Water-Environment-Rural Areas. 2008;8(2b):31-49.

2. Abaye AO, Allen VG, Fontenot JP. Influence of grazing cattle and sheep together and separately on animal performance and forage quality. J Anim Sci. 1994;72:1013-1022.

3. Harkot W, Lipińska H, Wyłupek T. Directions of land management changes on a background of natural conditions of agricultural production space in Lublin region. Acta Sci Pol. 2011;10(1):5-16.

4. Duffková R, Libichová $H$. Effects of cattle slurry application on plant species composition of moderately moist Arrhenatherion grassland. Plant Soil Environ. 2013;59:485-491.

5. Dumont B, Rook AJ, Coran CH, Röver KU. Effects of livestock breed and grazing intensity on biodiversity and production in grazing systems. 2. Diet selection. Grass Forage Sci. 2007;62(2):159-171. http://dx.doi.org/10.1111/j.1365-2494.2007.00572.x

6. Mosek B. Wpływ składu florystycznego zbiorowisk pastwiskowych dolin rzecznych Lubelszczyzny na ich wartość paszową. Zesz Nauk AR Krakow. 2000;368:235-240.

7. Rogalski M, Wieczorek A, Kardyńska S, Płatek K. Effect of grazing animals on floristic biodiversity of the sward. Zesz Probl Post Nauk Rol. 2001;478:65-70.
(Przytoczno), 69 species in the pastures extensively grazed by horses (Białka) and 37 species in the pastures extensively grazed by cows (Tarnogóra).

Hydrophytes and helophytes were the most numerous life forms in each of the pastures. Therophytes accounted for $19.7 \%$ of all life forms in the sward of the pastures for wild animals at Przytoczno and $10.5 \%$ in the sward of the pastures for horses at Białka, while at Tarnogóra this lifeform was not found.

The Shannon-Wiener diversity index for the sward of the pastures extensively grazed by horses was higher $\left(H^{\prime}=5.04\right)$ than for those extensively grazed by wild animals $\left(H^{\prime}=4.32\right)$ and cows $\left(H^{\prime}=3.53\right)$. The Simpson index of species diversity in a community was higher for the pastures grazed by horses $(S=0.96)$ than for those grazed by wild animals $(S=0.95)$ and cows $(S=0.90)$.

Extensive grazing of the sward by different animal species is an important factor in the preservation of biodiversity of plant communities and is essential for sustainable pasture. The knowledge of food preferences and the method of selection of feed for different species of animals should be used in the development of vegetation, especially the active protection of valuable grasslands that occur in extensively grazed pastures.

8. Warda M, Rogalski M. Grazing animals as an element of natural landscape. Ann UMCS Sec E. 2004;59(4):1985-1991.

9. Pielou EC. Ecological diversity. New York, NY: Wiley; 1975.

10. Simpson EH. Measurement of diversity. Nature. 1949;163:668. http:// dx.doi.org/10.1038/163688a0

11. Zarzycki K, Trzcińska-Tacik H, Różański W, Szeląg W, Wołek J, Korzeniak U. Ekological indicator values of vascular plants of Poland. Cracow: W. Szafer Institute of Botany, Polish Academy of Sciences; 2002. (Biodiversity of Poland; vol 2).

12. Mirek Z, Piękoś-Mirkowa H, Zając A, Zając M, editors. Flowering plants and pteridophytes of Poland - a checklist. Cracow: W Szafer Institute of Botany, Polish Academy of Science; 2002. (Biodiversity of Poland; vol 1).

13. Hejduk S. Species changeability of the botanical composition of pasture swards influenced by fertilising and renovation. Acta Univ Agric Silvic Mendel Brun. 2000;48:85-92.

14. Hejduk S, Hrabě F. Influence of different systems of grazing, type of swards and fertilizing on underground phytomass of pastures. Plant Soil Environ. 2003;49:18-23.

15. Liu W, Zhu YG, Christie P, Laidlaw AS. Botanical composition, production and nutrient status of an originally Lolium perenne-dominant cut grass sward receiving long-term manure applications. Plant Soil. 2010;326:355-367. http://dx.doi.org/10.1007/s11104-009-0016-z

16. Breitsameter L, Küchenmeister K, Küchenmeister F, Isselstein J. Tolerance to mechanical damage in ten herbaceous grassland plant species. Plant Soil Environ. 2012;58:334-339.

17. Kostuch R. The causes of the floristic diversity ocurrence on the grassland ecosystems. Ann UMCS Sec E. 1995;50(4):23-32.

18. Metera E, Sakowski T, Słoniewski K, Romanowicz B. Grazing as a tool to maintain biodiversity of grassland - a review. Anim Sci Pap Rep. 2010;28(4):315-334.

19. Rogalski M, Wieczorek A, Kardyńska S. Pasące się zwierzęta jako czynnik regulujący skład botaniczny runi. Fol Univ Agric Stetin. 1999;197(75):267-270.

20. Grodzińska K, Zarzycki K. Grazing communities of southern Poland. Zesz Probl Post Nauk Rol. 1967;74:11-28. 
21. Wolański P, Trąba C. Flora łąk i pastwisk Pogórza Dynowskiego. Water-Environment-Rural Areas. 2007;7(2b):195-204.

22. Loucougaray G, Bonis A, Bouzillé JB. Effects of grazing by horses and/or cattle on the diversity of coastal grasslands in western France. Biol Conserv. 2004;116(1):59-71. http://dx.doi.org/10.1016/ S0006-3207(03)00177-0

\section{Ocena składu florystycznego runi spasanej różnymi gatunkami zwierząt}

\section{Streszczenie}

Celem przeprowadzonych badań była ocena składu florystycznego pastwisk dla dzikich zwierząt (daniele, jelenie mandżurskie, muflony) w Przytocznie, pastwisk dla koni w Białce oraz pastwisk dla krów należących do wspólnoty gruntowej w Tarnogórze. Ocenę składu florystycznego badanych pastwisk przeprowadzono metodą Braun-Blanqueta w sezonie wegetacyjnym 2011 i 2012 roku. Na pastwisku dla dzikich zwierząt w Przytocznie wykonano 32 zdjęcia fitosocjologiczne, na pastwisku dla koni w Białce 32, a na pastwisku dla krów w Tarnogórze 38 zdjęć fitosocjologicznych. Różnorodność gatunkową badanych pastwisk określono na podstawie procentowego udziału gatunków z wyróżnionych rodzin botanicznych, ogólnej liczby gatunków oraz wskaźnika różnorodności Shannona-Wienera i Simpsona. Na pastwiskach dla koni występowało więcej gatunków niż na pastwiskach dla dzikich zwierząt i krów. Wskaźnik różnorodności Shannona-Wienera dla runi wypasanej przez konie był wyższy $\left(H^{\prime}=5.04\right)$, niż dla runi wypasanej przez dzikie zwierzęta $\left(H^{\prime}=4.32\right)$ i krowy $\left(H^{\prime}=3.53\right)$. Również wskaźnik różnorodności Simpsona był wyższy dla runi wypasanej przez konie $(S=0.96)$, niż runi wypasanej przez dzikie zwierzęta $(S=0.95)$ i krowy $(S=0.90)$. 